\title{
Approaches to Defining and Measuring Russia's Internet Economy
}

\author{
Sergey Plaksin ${ }^{a}$ \\ Deputy Director, Expert Analytics Office, splaksin@hse.ru
}

Gulnara Abdrakhmanova ${ }^{a}$

Head, Centre for Statistics and Monitoring of Information Society, Institute for Statistical Studies and Economics of Knowledge (ISSEK), gabdrakhmanova@hse.ru.

\section{Galina Kovaleva ${ }^{a}$}

Chief Expert, Centre for Statistics and Monitoring of Information Society, ISSEK, gkovaleva@hse.ru.

National Research University Higher School of Economics (HSE), 20 Myasnitskaya str., Moscow, 101000, Russian Federation.

\begin{abstract}
$\mathrm{T}$ We rapid development of digital technologies is changing production processes and forms of interaction. It has encouraged growing interest in electronic content and created a new segment of the economy where all actors rely on the internet. These processes are most noticeable in developed countries. Russia is no exception. The development of the domestic segment of the internet economy - the economy of the Runet - is of particular importance due to the size of the country, the significant socioeconomic heterogeneity and the underdevelopment of the transportation networks in the Russian regions. A study of the phenomenon of the internet economy requires a reliable information base. It is hard to provide an adequate quantitative estimate of the size of the internet economy for the following reasons. First, the existing statistical indicator system was created before the internet and internet businesses were widespread. Secondly, this new segment of economy is much more heterogeneous

than traditional sectors and industries and thus difficult to measure. This paper summarises the results of a review of international and Russian approaches on how to measure the internet economy. It also introduces a new way to measure the size of Russia's internet economy that is based on the principles of the System of National Accounts (SNA), using officially available statistical data, thus making this approach different from the previous recommendations. This new approach ensures a stable reproducibility of calculations, reliability and comparability of results as well as compliance with the standards of government statistics. The evaluation of the dynamics of economic processes that drive the internet economy was not in the scope of the study. This requires a separate study, including an analysis of how indices of constant quality that neutralize the effect of changes in consumer product properties and deflators are created The authors stipulate that these research areas hold independent interest.
\end{abstract}

\section{Keywords:}

internet economy;

online and offline business;

internet:

System of National Accounts (SNA). 
$\mathrm{T}$ he rapid growth and wide proliferation of services provided via the internet and of related technologies have been a major development in recent decades. The Federal Statistical Service's (Rosstat) data for 2005-2015 show more than three-fold growth of gross value added (GVA) created by computer and IT companies, compared with less than $30 \%$ growth of GDP during the same period. New communication formats and business practices turn into structural elements of the new, network technologies-based economy - the internet (or in our case, the Runet) economy. Usually it is seen as including internet service providers and companies making use of it.

The goal of our study is to identify approaches to measuring the Runet economy using statistical analysis, sociological research, and institutional design techniques. The proposed methodology takes into account international experience and meets scientific validity and practical applicability requirements.

\section{International studies of the internet economy}

Although no standardised methodology for measuring the internet's impact on the economy and social sphere has yet been developed, numerous studies were devoted to this topic. The better-known and respected ones include research by the Organisation for Economic Cooperation and Development (OECD) and by several consulting firms [OECD, 2013; McKinsey, 2011; BCG, 2012]. All previously conducted studies in this area can be divided into two groups.

Studies in the first group focus on the factors affecting the internet economy and on measuring its potential. Various indices are applied to evaluate the internet's penetration, specific technological infrastructure characteristics and economic indicators of how this infrastructure can be accessed, levels of internet use, and indirect characteristics, e.g., human capital [BCG, 2011, 2013, 2014; McKinsey, 2011]. The second group of studies includes research on of the internet's direct [Deloitte, 2011; OECD, 2013; McKinsey, 2011; BCG, 2012] and indirect impacts on the economy [Stiglitz et al., 2009; BCG, 2010] and social sphere [OECD, 2013; Shah et al., 2001; Morton, 2006; Greenstein, McDevitt, 2011].

\section{Factors affecting the internet economy's growth}

Researchers distinguish between supranational, national, and regional factors affecting the development of the internet economy. James Agarwal and Terry Wu [Agarwal, Wu, 2015] discuss importance of supranational factors such as (1) the development of free trade, (2) companies' willingness to do business in other countries, (3) information and communication innovations providing competitive advantages to companies all over the world, and (4) the development of infrastructure for international transactions and their security. The authors include government support and promotion of innovation and investments, rule of law, and the availability of the adequate technological, financial, and social infrastructure in the national-level group of factors. According to the researchers, the main barriers hindering the growth of the internet economy include the technological gap between developed and developing countries and the latter's inability to guarantee the rights of consumers who buy goods and services on the internet.

Stephen Knight's study [Knight, 2015] is based on Australian data and is focused on the analysis of regional factors affecting the growth of internet economy. He states that predominantly agricultural states lag behind in this area due to a lack of broadband internet access. Therefore, relevant infrastructure is necessary to overcome the gap between agricultural regions and other parts of the country. Apart from broadband networks, it also includes access to major informational, educational, and other internet resources. At the same time, the author stresses that ICT infrastructure is not the only factor affecting regional economic growth and it certainly does not guarantee it.

Desirée van Welsum and her colleagues note the strong correlation between economic growth in the EU and advances in the development and proliferation of ICT [van Welsum et al., 2013]. By the mid2000s, this factor has no longer remained among major growth drivers due to several reasons such as the reduced investments in ICT, infrastructure, and production of innovative high-tech products as a result of the economic recession; a lack of an integrated regulatory system, and shortage of skilled personnel. The proliferation of mobile broadband internet, Big Data, and cloud technologies can help ICT regain its former influence.

Eric Labaye and Jaana Remes [Labaye, Remes, 2015] name specific conditions required for further growth of the internet economy:

- The creation of a system of incentives encouraging productivity growth and innovation. A good example is the rapid growth of productivity in the US during the 1990s due to the competitive environment, which was stimulated higher market competitiveness than that in Europe or Japan. Deregulated markets and low entry barriers for new businesses created favourable conditions for the ICT industry.

- The funding of ICT-related research: basic studies by the government, applied ones - by interested private companies;

- The development of human capital by promoting educational programmes that develop competencies required in high-tech industries (e.g. initiatives in natural and engineering sciences, ICT, and mathematics are being implemented in the US on the federal, regional, and local levels);

- The development of mechanisms providing access to open data sources; 
- The promotion of foreign investments in ICT infrastructure; eliminating barriers hindering the flow of products, services, and human capital.

\section{Measuring the internet's impact on the economy}

The internet affects the economy directly and indirectly. The direct impact includes the combined contribution of all sectors of the internet economy to GDP [BCG, 2012; Deloitte, 2011; OECD, 2013; etc.], while indirect impact affects all industries, even those that are not directly related to the internet. For example, the worldwide webs impact on the transportation industry can be measured via revenues of companies and entrepreneurs who make use of aggregator services such as Yandex.Taxi, Uber, Gett, etc., and "conventional" carriers whose revenues drop due to the proliferation of online economic mechanisms [Stiglitz et al., 2009; BCG, 2010].

The method based on end-use of revenues is most frequently used to assess the internet's direct impact on the economy. Essentially quite homogenous, such calculations significantly vary in terms of expenditures included in the "consumption", "investments", "public spending", and "net exports" groups. Data for calculations was taken from publications by national statistical services, Eurostat, the OECD, Gartner company, and surveys conducted by Google and IAB Europe. Also, in the absence of official statistics, analysts occasionally use specially designed proxy indicators. The internet economy measurement formula suggested by BCG [BCG, 2012] seems to be best suited for the purposes of our study:

\section{Internet economy $=$ Consumption + Investment + Public Spending + Net Exports}

Consumption includes expenditures on buying products and services on the internet; internet access costs; payments to internet service providers; and the procurement of equipment. Internet access costs include landline and mobile access, and partially the purchase of computers, mobile phones, and network equipment (e.g., wireless routers). Investment includes investments made by companies, specifically by those in telecommunications, in capital assets required for landline and mobile internet access, except software development. Public ICT-related spending includes the procurement of computer hardware and software and payments for telecommunications and related services. Net exports are defined as the difference between the value of exported and imported products and services procured or provided online, and expenditures on ICT equipment, calculated on the basis of e-commerce and hardware sales data.

Certain individual researchers also apply this approach. For example, Dale Jorgenson and Kevin Stiroh [Jorgenson, Stiroh, 2000] calculate ICT production potential and the impact on economic growth in the US during the 1990s as combined investments in computer hardware, software, and communication systems and expenditures on ICT-related consumer products. The production-based technique for the calculation of the added value created by the internet sector companies [Deloitte, 2011; OECD, 2013] is used less frequently. The main problem with this approach is insufficiently detailed statistical data available through the UN System of National Accounts (SNA) and the Standard Industrial Classification of All Economic Activities (ISIC). Moreover, there is a lack of data on companies' operations on the internet. Another limitation is due to the fact that these classifications do not distinguish between the sectors' online and offline activities in all spheres. This leads to type I and II errors related to identified boundaries of the internet economy and the amount of online operations. In other words, with this approach, activities totally unrelated to the internet are inevitably included in the internet economy calculations, or ignore certain online activity that is not recorded as official statistical data.

Hasan Bakshi [Bakshi, 2016] notes that there is no commonly accepted definition of the internet economy in the UK, while definitions provided in the early (50-year old) versions of the SNA apply to material production and are not valid for measuring the internet economy. Bakshi suggests distinguishing between the digital industry proper, which is comprised of producers of electronic products and services (i.e. companies for whom they constitute the main source of income), and the digital economy, which involves the use of software and hardware in other industries. Bakshi writes that companies using advanced technologies in industries such as healthcare or education, should not be included in the groups whose codes are attributed to hardware and software producers. He also points out that annual surveys conducted by the UK Office for National Statistics cover almost none of the micro-companies, many of which develop new technologies.

The study [Bakshi, 2016] pays particular attention to problems associated with classifying activities of companies like Amazon (online trade in e-books and physical products), Spotify (music streaming), and Airbnb (worldwide short-term renting of private dwellings) which do not match the ISIC "main economic activity" definition. Spotify, as well as Google, are included in the UK in the "Other business services not included in other groups" category, while the service's contribution to music industry statistics is not reflected - leading to obvious gaps in calculations. In addition to reviewing the classification of economic activity types, the adoption of various alternative calculation methodologies by the UK Office for National Statistics would help produce more accurate data about the size of the internet economy.

The US has the best toolset for the statistical measurement of e-commerce; relevant data are collected by the Bureau of Economic Analysis (BEA) of the U.S. Department of Commerce. Still, some researchers (see, e.g., [Brynjolfsson, Saunders, 2010]) note certain shortcomings of the BEA methodology which includes the activities of computer and other hardware manufacturers, companies providing relevant 
maintenance services, and producers of ICT services (software developers, telecommunication operators, etc.) in the calculation of generated gross value added.

In order to estimate the volume of the internet economy on the basis of value added, Deloitte uses a methodology that accounts for revenues generated by internet service providers, search engines, data storage and processing systems, computer hardware dealers, IT consultants and software distributors, new media and podcasters, advertising agencies and web developers, and providers of public online services [Deloitte, 2011].

The OECD always recommended using the SNA for calculating the value added [OECD, 2010]. In 2011, this organisation initiated a series of studies aimed at developing a methodology for measuring the internet economy. The studies were based on existing projects and previously formulated statistical definitions [OECD, 2011]. Subsequently, it was suggested that ISIC criteria be used to standardise data and make international comparisons possible [OECD, 2014], but only the US (the annual BEA reports) and Australia (just once) followed this recommendation [Deloitte, 2011]. The OECD recommendations stress the challenges associated with applying this approach as the available data are limited.

\section{The internet's impact on the social sphere}

ICT has yielded a whole range of next-generation products and services such as distant learning, telemedicine, cloud file sharing, etc. At the same time, the internet's role is not limited to activities of relevant market players: its impact is much broader, directly affecting the social and consumer spheres including the creation and application of social capital. The abovementioned effect is evident in emergence of e-health, e-learning, and e-government services [OECD, 2013; Shah et al., 2001; Morton, 2006; Greenstein, McDevitt, 2011].

Speaking about the internet's impact on the environment, experts turn to "green economy" concepts. According to Carmen Ciocoiu [Ciocoiu, 2011], ICT advances have significantly transformed the environment, primarily through application of innovative technologies, the proliferation of electronic applications and e-commerce. Specifically, the reduced consumption of electricity and more efficient energy usage were noted. Distant learning technologies have allowed for reducing work-related travel and commuting, and accordingly, the amount of harmful emissions. The ICT-based green economy's growth is taking place in three major areas [Ciocoiu, 2011]:

- Increased energy and material efficiency, wide use of renewable energy sources, increased waste recycling, reduced toxicity of substances;

- Increased efficiency of production, distribution, and consumption of products and services due to the reduced costs of energy and other resources, and their partial or complete replacement by virtual equivalents;

- The continuous adjustment of consumer behaviour and values due to the promotion of various ways to reduce one's negative impact on the environment.

\section{Measuring the internet economy: the Russian experience}

Despite the large number of quantitative internet business studies published in Russia, there were relatively few attempts to measure the size of the Russian internet economy. Depending on the study goals, this research can be divided into several categories: the analysis of the audience and the structure of the Russian segment of the internet; the assessment of specific online markets and the study of the Runet economy as a whole.

The first group includes studies frequently cited by large think tanks that are focused on analysing various online market segments (see, e.g., [TNS, 2014; SSC Enter, 2014]). The most well-known studies of the second group include those conducted by the Association of Internet Trade Companies [AITC, 2014], Data Insight [Data Insight, 2014], and East-West Digital News [EWDN, 2013]. They summarise the authors', or other companies' quantitative assessments (volume and dynamics of electronic sales) for various narrow segments of the Russian online market, such as electronics and home appliances, clothes and footwear, car parts, video games, tickets, etc. The results of these studies s are highly reliable and discrete, because surveyed companies combine online and offline activities. However, such survey data are poorly suited for reproduction and comparison.

To date, the only comprehensive study of the Russian internet economy based on an original methodology is the annual reports by the Russian Association of Electronic Communications (RAEC) [RAEC, 2012, 2013, 2014, 2015]. The RAEC experts analyse structural dynamics of the Russian online market in several segments: marketing and advertising (media, context, video, mobile advertising, search engine optimisation (SEO), social media marketing (SMM)); infrastructure (SaaS, hosting, domains); e-commerce (retail, tourism, payments), and digital content (books and media, games, music, and videos $)^{1}$. The study includes two stages: during the first stage, Foresight consultations are conducted with

The sectors covered by the RAEC study have changed every year since 2011. Here and below, unless specifically noted otherwise, the methodology and data are described for the [RAEC, 2015] study. 
leading industry experts and the second stage involves the survey of a wider range of industry experts. Data collected for each segment of the internet economy underpin the calculation of integral indicators measuring market size, growth rate, structure, external factors affecting its development, potential, and growth points.

\section{Methodology}

A methodology based on the SNA principles seen as a set of interconnected indicators can be used to assess the actual scale of the Russian internet economy segment. It is used to describe and analyse macroeconomic processes in more than 150 countries. The main methodological provisions of the SNA are harmonised with the balance of payments, GDP, and other key indicators. A comprehensive statistical toolset for GDP is available to capture patterns, growth trends, and interconnections. This approach has many advantages such as regular data collection, a clear calculations programme, and it meets scientific validity and practical applicability requirements. Although this approach is not completely free from minor drawbacks, we will not dwell on them here.

Two SNA techniques for measuring GDP can be applied to assess the size of the internet economy: production-based (value added) and end-use-based (expenditures). Data sources for the application of the aforementioned methodology included our own surveys and official data published by Rosstat, the Russian Ministry of Communications and Mass Media, the Federal Customs Service, and Bank of Russia, which was sufficient for making proper comparisons between various sectors of the economy. The proposed methodology takes into account international practices and the specificity of the Russian national statistics system.

\section{Production-based measurement of the internet economy}

The production-based approach for measuring the internet economy is based on the combined GVA produced by companies operating online. According to the SNA methodology, GVA is calculated at the industry and sector levels and is defined as the difference between their products' and services' output and intermediate consumption. The output is calculated as the combined value of products produced by resident companies during the accounting reference period. Intermediate consumption means the value of products and services transformed or fully consumed in the course of the production process during the accounting reference period [Rosstat, 2015].

\section{The internet economy's place in the classification of economic activities}

Three major economic sectors are considered based on the role the internet plays in companies' operations and include: (1) ICT infrastructure and its maintenance; (2) online business only, and (3) both online and offline operations. The first group comprises companies which create, implement, and develop ICT systems, resources, and components. The second includes typical internet economy actors that perform all their production processes on the web: they design and provide services, participate in e-commerce, etc. The third group is composed of companies that directly interact with clients, supplying them with products and providing services, both online and offline, in areas such as tourism, ICT infrastructure,banking, retail, airline and railway tickets sellers, and real estate.

In order to measure the size of the internet economy using the production-based technique, we should first clearly define the segment's boundaries in line with the All-Russian Classification of Economic Activity Types (OKVED) (the 1.1 edition valid at the time of the study) ${ }^{2}$. This version of OKVED allowed the authors to test our methodology using real statistical data but also led to certain limitations. For example, companies operating exclusively on the web can be classified as IT or retail e-commerce firms only. Online market players such as airline and railway ticket sellers, real estate agents, advertisers, marketing and banking companies are not present in the classification, so they can be counted only at the level of companies performing both online and offline business operations. International researchers also face similar problems with the statistical measurement of the internet economy using conventional classifications.

With a certain degree of approximation, the internet economy can be mapped on the basis of the OKVED edition 1.1 as follows:

- The ICT infrastructure and its maintenance sector includes telecommunication and information companies (codes 64.20.12, 64.20.3, 64.20.4, 64.20.5, 64.20.6, 64.20.7, 72.1, 72.2, 72.6);

- The online business sector includes companies engaged in retail e-commerce, data processing, the creation and application of databases as well as other online resources (codes 52.61.2, 72.3, 72.4);

\footnotetext{
${ }^{2}$ OKVED edition 1.1 was approved by the Federal Agency on Technical Regulating and Metrology, order of 22.11.2007 No 329-st (edition of 24.12.2012). In 2014, a new edition of the classification was approved - OKVED-2 (OK 029-2014 (NACE Rev. 2) (order of 31.01.2014 No 14-st), and came into effect as of 01.01.2017 (Rosstat order of 20 November 2015 No 560). We see a revision of the internet economy's structure and boundaries in line with the OKVED-2 as our future objective, but we can already note that the new classification will allow for overcoming various limitations encountered when the OKVED edition 1.1 was used.
} 
- The online and offline business sector includes publishing, transport, and advertising companies, financial brokerage and insurance firms, production, distribution, and screening of films, radio and TV broadcasting, retail, and travel (codes 22.1, 52.1, 52.2, 52.3, 52.4, 52.5, 52.6 (except 52.61.2), 63.21.1, 63.21.21, 63.22.11, 63.23.1, 63.3, 65, 66, 74.4, 92.1, 92.2, 92.4).

The general breakdown of internet economy companies by economic activity type on the basis of the OKVED is presented in Table 1.

\section{Measuring the size of the internet economy}

When the size of the internet economy is measured, all GVA generated by companies of the first two sectors are counted, while the third sector requires estimating the share of online business in the companies' operations. The general formula for calculating GVA for all sectors looks as follows:

$I E G V A=G V A_{1}+G V A_{2}+G V A_{3}{ }^{*} K$,

where IE GVA is the GVA generated by companies engaged in internet business activities; GVA is the GVA generated by the ICT infrastructure and its maintenance sector; $G V A_{2}$ is the GVA generated by companies engaged exclusively in online business; $G V A_{3}$ is the GVA generated by companies operating both online and offline; and $K$ is the share of their online business.

$\mathrm{GVA}_{1}, \mathrm{GVA}_{2}$, and GVA 3 are calculated for all economic activity types in each sector (see Figure 1), with Rosstat SNA data serving as the starting point. Direct statistics are available for publishing; production, distribution, and screening of films; radio and TV broadcasting; financial brokerage and insurance. Measuring GVA generated by companies specialising in other areas involves identifying the closest activity types in relevant classification groups. For example, the retail e-commerce segment can be measured via the GVA generated by such companies only on the basis of the composite group "Retail trade except automobiles and motorcycles; repair of home appliances and personal effects; retail sale of motor fuel" (codes 52, 50.5). GVA generated by the internet economy includes value added created by

\section{Table 1. Suggested structure of the internet economy based on the OKVED edition 1.1}

\begin{tabular}{|c|c|}
\hline Sector & Economic activity types \\
\hline $\begin{array}{l}\text { ICT infrastructure } \\
\text { and its maintenance }\end{array}$ & $\begin{array}{l}\text { Communication } \\
\text { - mobile communications }(64.20 .12) \\
\text { intersystem communications }(64.20 .3) \\
\text { - data transfer (64.20.4) } \\
\text { - telematics (64.20.5) } \\
\text { cable TV broadcasting, on-air TV broadcasting, cable radio broadcasting (64.20.6) } \\
\text { - other telecommunication services (64.20.7) } \\
\text { - computer hardware consulting (72.1) } \\
\text { - software development and related consulting (72.2) } \\
\text { - other computer- and IT-related activities (72.6) }\end{array}$ \\
\hline Online business & $\begin{array}{l}\text { Retail } \\
\text { - retail operations performed directly via TV, radio, by telephone, or on the internet (52.61.2) } \\
\text { IT services } \\
\text { - data processing }(72.3) \\
\text { - the creation and application of databases and other information resources, including internet-based ones } \\
(72.4)\end{array}$ \\
\hline $\begin{array}{l}\text { Online and offline } \\
\text { business }\end{array}$ & 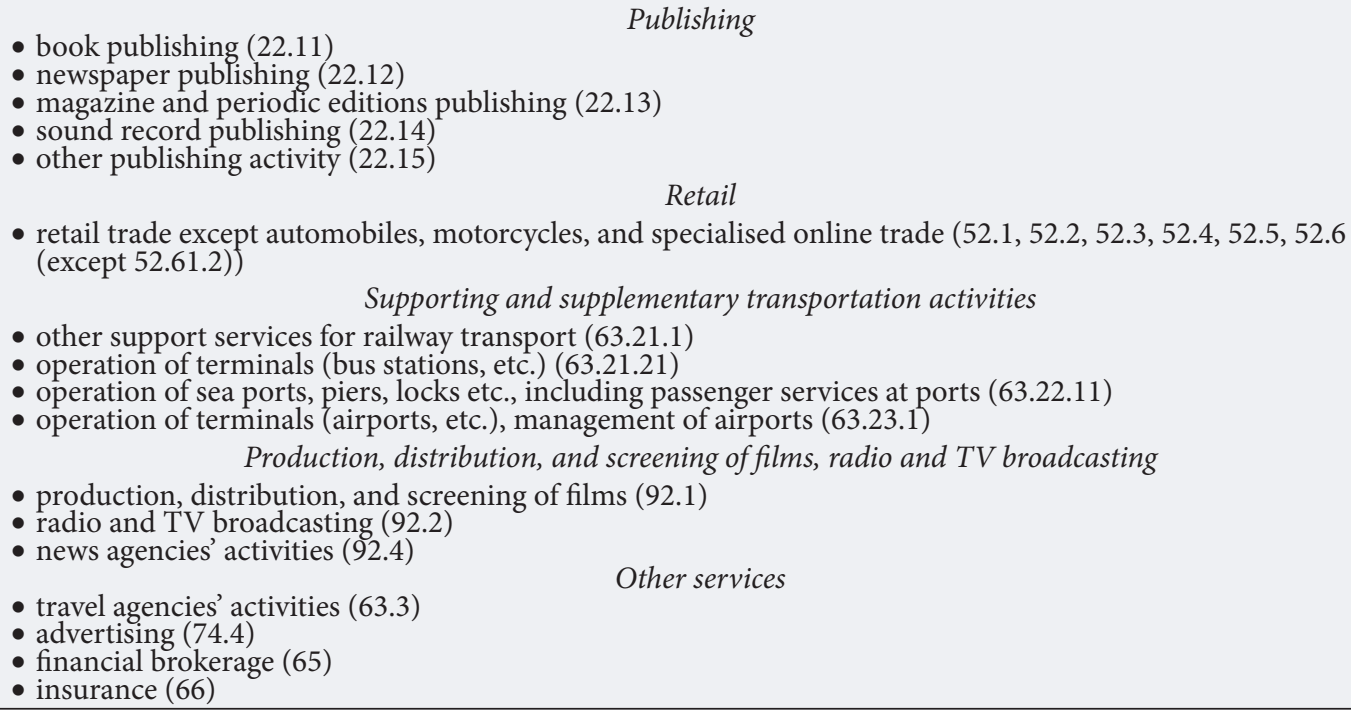 \\
\hline
\end{tabular}




\section{Figure 1. The size of the Russian internet economy: 2014 (billion roubles)}

Production-based technique (value added)
End-use method (based on expenditures)
Companies operating

online and offline

Companies operating
solely online

ICT infrastructure and its maintenance
342

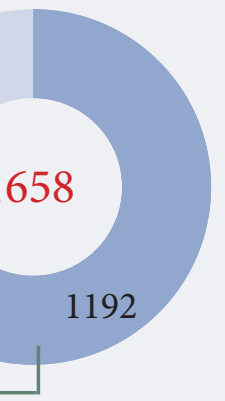

124

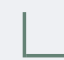

$\mathrm{GDP}=100 \%$

Source: [Abdrakhmanova et al., 2016a].

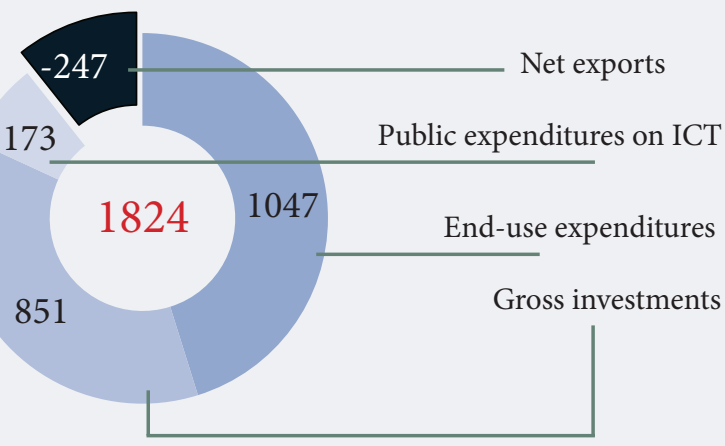

Internet economy $-2.6-2.7 \%$

retail companies operating exclusively online (52.61.2) $\left(\mathrm{GVA}_{2}\right)$ and by offline retail companies except those selling vehicles and motorcycles $(52.1,52.2,52.3,52.4,52.5,52.6$ (except 52.61.2)) which do both online and offline business $\left(\mathrm{GVA}_{3}\right)$.

A specific range of data sources was identified for each activity type, and GVA sub-indicators were calculated. In line with international practice (for example, the OECD's attempt to measure the US internet economy [OECD, 2013]), these calculations were based on a hypothesis about sales and revenue structures matching the GVA structure. Industry-specific and corporate statistics for the following indicators were used:

- GVA (except for small enterprises) disaggregated to the level of economic activity types such as retail (except e-commerce), IT industry, advertising, and news agencies' operations;

- (e-commerce) retail turnover;

- output (products and services) (transport, travel)

- service-generated revenues (telecommunications) $)^{5}$.

In terms of methodology and the collection of initial data, the biggest problem is identifying the internet share of GVA generated by companies engaged both in online and offline business operations. As with mapping economic activities, the estimates were based on the assumption that a structural similarity exists between sales and GVA. To measure the share of the electronic sales of financial, advertising, and transportation companies, firms engaged in the production, distribution, and screening of films, radio and TV broadcasters, and news agencies, we suggest assessing the level of their sales on the internet (and other global information networks) on the basis of orders received or placed on the website, in the extranet, or through electronic data interchange (EDI) systems $s^{6}$. For insurance, publishing, retail, and travel companies, the share of electronic sales was estimated by conducting a special survey which was comprised of in-depth interviews with representatives of each of the four industries and a telephone poll of insurance and travel firms [Abdrakhmanova et al., 2016c].

\section{End-use-based measurement of the internet economy}

The end-use-based technique amounts to summing up households' consumption expenditures, gross investments, public expenditures on ICT, and net exports. The formula can be expressed as follows:

$I E G V A=P_{e c}+P_{g i}+P_{s}+N E$,

\footnotetext{
${ }^{3}$ Federal statistical survey form "Basic information about the organisation's activities" (No 1-enterprise), approved by the Rosstat order of 15.07.2015 No 320.

${ }^{4}$ This indicator and the previous one are both included in the federal statistical survey form "Information about production and shipment of products and services" (No P-1), approved by the Rosstat order of 15.07.2015 No 320.

${ }^{5}$ Federal statistical survey form "Information about revenues generated from communication services" (No 65-communication (services)), approved by the Rosstat order of 12.03.2015 No 95.

${ }^{6}$ Federal statistical survey form "Information about the application of information and communication technologies, production of computer hardware, software, and provision of related services" (No 3-inform), approved by the Rosstat order of 03.08 .2015 No 357.
} 
where IE GVA is the size of the internet economy calculated on based on expenditures; $\mathrm{P}_{e c}$ is end-use consumption; $\mathrm{P}_{g i}$ is gross investments; $\mathrm{P}_{s}$ is public spending on ICT, and NE is net exports.

End-use consumption expenditures include population's acquisition of ICT equipment, online purchases, and internet access costs. Gross investments include companies' expenditures on computer hardware, telecommunication equipment and software, capital investments by companies specialising in the creation and maintenance of ICT infrastructure, and by firms doing business exclusively online. Public ICT expenditures include the procurement of hardware, software, and related services. Net exports is the difference between the value of exports and imports of ICT products and services. Sources of data on relevant expenditures included the Rosstat's household surveys, structural statistics for enterprises, trade, information society, customs turnover, Russia's balance of payments, and information about ICT-related public procurement contracts (products and services).

\section{End-use consumption}

Expenditures on purchasing products on the internet can be measured either from the consumption side, or on the basis of online suppliers' data. The first approach offers certain advantages since it allows for the consideration of purchases made both in Russia and elsewhere. However, no relevant official statistics or survey data are available. The second approach allows one to measure the e-commerce market using retail turnover figures, specifically data about the share of online orders. Due to a lack of relevant statistics for food products, only retail turnover for non-food products was taken into account. However, as the analysis of consumers' structure shows, this did not significantly affect our final results. In 2014, the share of the population who have purchased food products on the internet was $9 \%$ of all people who made online purchases, and $2 \%$ of the total population aged between $15-72$ [Abdrakhmanova et al., 2016b].

A key methodological issue of measuring the e-commerce market is determining its scope: i.e., if it should include only products sold and delivered to consumer online (such as software, computer games, audio and video content, etc.), or also include a whole range of products ordered on the internet at a full price. Following the established practices [McKinsey, 2011; BCG, 2012], we have chosen the second approach, given that the purchase of digital or non-digital products on the internet is the result of online operations. Thus, people's expenditures on online purchases were calculated on the basis of retail turnover for nonfood products and the share of online orders in the latter.

Households' expenditures on acquisition of ICT equipment include the procurement of personal computers, periphery, components, and other data processing hardware and spare parts ${ }^{7}$. Since some of these expenditures were counted under the heading "Households' expenditures on the procurement of products on the internet", the amount was adjusted to account for the share of online sales in the total sales of non-food products. Expenditures on internet access include data from the relevant household expenditures item ${ }^{8}$.

\section{Gross investments}

Companies' expenditures on the procurement of computer hardware, telecommunication equipment and software include purchases of all kinds of computers, periphery devices (printers, scanners, backup data storage devices, additional monitors, etc.); TV and radio transmitting devices, electrical equipment, software, operating systems, design and software development tools, and other support and secondary products. Data for large and medium companies (except secondary and vocational schools ${ }^{9}$ ) includes information provided in the relevant federal statistical survey form ${ }^{10}$. Obtaining data on ICT-related expenditures by all companies would require recalculating their costs by comparing staff numbers of large and medium companies with the total number of those employed. The relevant expenditures of firms, players on the market for ICT infrastructure and its maintenance, and of companies doing exclusively online business were not taken into account because these amounts were included in the capital investments category, i.e., they had already been counted as part of companies' gross investments ${ }^{11}$.

\section{Public expenditures on ICT}

Data about the procurement of products and services, or about ICT-related contracts are the main source of information on relevant public spending. The former has an advantage of legally established

\footnotetext{
${ }^{7}$ Federal statistical survey form "Household budget survey questionnaire" (No 1-V), approved by the Rosstat order of 03.02 .2016 No 37.

${ }^{8}$ Ibid.

${ }^{9}$ Form P-2 “Information about investments in non-financial assets", approved by the Rosstat order of 17.07.2015 No 327.

${ }^{10}$ Federal statistical observation form "Information about the application of information and communication technologies, production of computer hardware, software, and provision of related services" (No 3-inform), approved by the Rosstat order of 03.08.2015 No 357 .

${ }^{11}$ Federal statistical survey form No PM “Information about basic indicators of the small enterprise's activities", approved by the Rosstat order of 15.07.2015 No 320
} 
indicators and strict requirements for documenting budget execution; the latter are accounted for by the relevant executive agencies, local self-government organisations, and various institutions at all levels, in the framework established by the Federal Law of 05.04.2013 No 44-FZ "On the contract system for the procurement of products and services to meet state and municipal needs" An analysis of completeness and reliability of data from the above sources revealed that information about public procurement of ICT-related products and services presented as combined contract value is better suited for the purposes of measuring the Russian internet economy ${ }^{12}$.

\section{Net exports}

The difference between the value of exports and imports of computers, periphery devices, and relevant computer-related and information services is calculated using balance of payments data published by the Central Bank of Russia. Computer-related services include services related to hardware, software, and data processing; information services include news agencies' operations, databases (from concept design to data storage and distribution, via online networks or on magnetic, optical, and printed media), and search engines. Exports of computers and periphery devices are calculated on the basis of customs statistics in line with the Product Nomenclature for External Economic Activities ${ }^{13}$.

\section{Results}

The experimental calculation of the GVA generated by and combined expenditures of the internet economy on the basis of the methodological approaches described above yielded the following results. Calculated using the production-based technique, the GVA generated by the internet economy in 2014 amounted to 1.658 trillion roubles. ${ }^{14}$ More than $70 \%$ of this amount was produced by the ICT infrastructure and maintenance sector, about $20 \%$ - by companies operating both online and offline, and $7 \%$ - by companies solely engaged in online business. Combined internet-related expenditures in 2014 amounted to 1.824 trillion roubles, the bulk of which were end-use consumption and investments (Figure 1).

The internet economy's contribution to GDP, calculated using both techniques, amounted to approximately $2.6-2.7 \%$ in 2014. To compare, the relevant figures for such sectors of the economy as production, transportation, and distribution of electricity, gas, and water were $2.9 \%$; for agriculture $-3.9 \%$; land transportation $-4.1 \%$; and financial brokerage $-4.5 \%$. Production-based and end-use-based methods yielded similar results, which confirms the validity of the estimates. When harmonised with international approaches, these methods allow one to compare across various countries. Therefore, our estimates of the internet economy in 2014 are comparable with the BCG forecasts for Russia for 2016 and the results of other international and Russian studies (Table 2).

In terms of the internet economy's development, Russia is ahead of Brazil (2.4\% of the GDP) and Turkey (2.3\%), and close to Argentina (3.3\%) [BCG, 2012]. At the same time, the internet economy of Great Britain, the leader with a GDP share at $12.4 \%$, is 4.8 times greater than that of Russia [Abdrakhmanova et al., 2016a].

\section{Conclusion}

The analysis of international experience revealed that, despite the obviously increasing role of the internet sector of the economy, there is still no universally accepted methodology for measuring it. There is no consensus on this issue, not solely in Russia but also internationally. Organisations studying the internet's impact on the economy and social sphere use various approaches. The OECD and major consulting firms such as McKinsey, BCG, Deloitte, etc. continue their research, test various original methodologies, and are still getting ready to make generic recommendations. Each of these organisations is working on its own original methods and measurement tools; all of them calculate their own specific indices. Russian researchers tend to measure the internet economy's share of GDP by calculating relevant expenditures of all economic agents. The approach presented in this paper is compatible with the SNA methodology and international practices and is based upon the use of official statistics, thus ensuring the reproducibility and reliability of the final results.

The application of the suggested methodology (including classification) and data collection for measuring the size of the internet economy based on the production method and end-use methods demonstrates that these methods are preferable for such measurements. However, the production-based approach does have certain limitations, namely the notional division of the internet economy into sectors on the basis of OKVED, which leaves a significant proportion of companies in the classification's "blind zone". Other limitations include a probability of errors with the GVA measurement caused on the one hand by the

\footnotetext{
${ }^{12}$ The official website of the unified information system for procurement on the Internet: http://zakupki.gov.ru/ (last accessed on 01.12.2015).

${ }^{13}$ Approved by the Eurasian Economic Commission's Council, decision of 16.07.2012 No 54 .

${ }^{14}$ Calculated on the basis of the Rosstat's SNA data and industry-specific statistics for 01.12.2015.
} 
Table 2. Comparative estimates of the size of the Russian internet economy

\begin{tabular}{|c|c|c|c|c|}
\hline \multirow{2}{*}{ Study } & \multirow{2}{*}{ Conducted by } & \multirow{2}{*}{ Year } & \multicolumn{2}{|c|}{ Volume of the Russian internet economy } \\
\hline & & & billion roubles & $\%$ of GDP \\
\hline $\begin{array}{l}\text { Structure and volume of the internet } \\
\text { economy }\end{array}$ & HSE & 2015 & $1658^{*} ; 1824^{* *}$ & $2.6-2.7$ \\
\hline Runet economy in 2014-2015 & RAEC & 2015 & $1570^{* * *}$ & 2.2 \\
\hline \multirow{2}{*}{ The internet economy in the G-20 } & \multirow{2}{*}{ BCG } & 2010 & $810^{* *}$ & 1.9 \\
\hline & & 2016 (forecast) & - & 2.8 \\
\hline \multicolumn{5}{|c|}{$\begin{array}{l}\text { Notes: } \\
\text { "Calculated using production-based technique. } \\
\text { Calculated using end-use-based technique. } \\
\text { capture internet access costs, investments in internet companies, and electronic B2B commerce [RAEC, 2014]. In 2015, the combined volume of these } \\
\text { markets was estimated at } 11.8 \text { trillion roubles. }\end{array}$} \\
\hline \multicolumn{5}{|c|}{ Source: [Abdrakhmanova et al., 2016a]. } \\
\hline
\end{tabular}

level of detail of the OKVED-based calculations (to the fifth or sixth digit), and on the other - by using a limited nomenclature of economic activities and an incomplete sample of organisations to calculate the share of companies' online operations.

A more precise expenditure-based measurement of the internet economy requires the further improvement of the collection and processing of data on online purchases for consumption purposes (by individuals and households), excluding retail statistics. A methodology must be developed and the range of data sources should be expanded for measuring the population's expenditures on the procurement of services on the internet. Accomplishing these objectives will improve the quality of measuring purchases from international online suppliers. The current typology of expenditures on the internet activities also needs to be revised, e.g. by adding companies' internet access costs. Yet another task is the development of a mechanism for collecting data on public ICT-related expenditures, broken down by procurement and budget spending at all levels.

The results presented in this paper were obtained during research sponsored by the RF Ministry of Education and Science (project RFMEFI60215X0011)

\section{References}

Abdrakhmanova G., Gokhberg L., Kevesh M., Kovaleva G., Kotsemir M., Kuznetsova I., Lola I., Ostapkovich G., Polyakova V., Ryzhikova Z.., Fridlyanova S., Fursov K. (2016b) Indikatory informatsionnogo obshchestva: 2016. Statisticheskii sbornik [Information society indicators: 2016. Data Book], Moscow: HSE. Available at: https:// www.hse.ru/primarydata/iio2016, accessed 27.07.2016 (in Russian).

Abdrakhmanova G., Gokhberg L., Kovaleva G., Plaksin S., Shchigolev B., Yastrebova E. (2016c) Metodologicheskie rekomendatsii po issledovaniyu struktury i razmera internet-ekonomiki v Rossii [Methodological Manual for Analysis of Structure and Size of the Russian Internet Economy], Moscow: HSE. Available at: http://bit. ly/2INNR5d, accessed 27.07.2016 (in Russian).

Abdrakhmanova G., Kovaleva G., Plaksin S. (2016) Approaches to defining and measuring Russia's internet economy (HSE Working Paper Series: Science, Technology and Innovation. WP BRP 61/STI/2016), Moscow: HSE.

Abdrakhmanova G., Kovaleva G., Plaksin S. (2016a) Internet-ekonomika Rossii [Internet-economy in Russia]. Information Society. Monitoring (Information newsletter no 4 (9)), Moscow: HSE. Available at: https://www. researchgate.net/publication/305165644_Internet-ekonomika_Rossii, accessed 27.07.2016 (in Russian).

Agarwal J., Wu T. (2015) Factors influencing growth potential of e-commerce in emerging economies: An institutionbased N-OLI framework and research propositions. Thunderbird International Business Review, vol. 57, no 3, pp. 197-215.

AKIT (2014) Rynok e-commerce. Itogi pervogo polugodiya 2014 [The market of e-commerce. Results of the first half 2014], Moscow: AKIT. Available at: akit.ru/wp-content/uploads/2014/10/Рынок-e-commerce-2с-итогипервого-полугодия-2014.pdf, accessed 27.07.2016 (in Russian).

Bakshi H. (2016) How can we measure the modern digital economy? Significance, vol. 13, no 3, pp. 6-7.

BCG (2010) The Connected Kingdom. How the internet is transforming the U.K. Economy, Boston: The Boston Consulting Group. Available at: https://www.bcg.com/documents/file62983.pdf, accessed 21.03.2016.

BCG (2011) Turning Local, Boston: The Boston Consulting Group. Available at: https://www.bcgperspectives. com/content/articles/technology_telecommunications_turning_local_from_madrid_to_moscow_internet/, accessed 21.03.2016.

BCG (2012) The Internet Economy in the G-20, Boston: The Boston Consulting Group. Available at: https://www. bcg.com/documents/file100409.pdf, accessed 21.03.2016.

BCG (2013) The 2013 BCG e-Industry Index. Available at: https://www.bcgperspectives.com/content/articles/digital_ economy_telecommunications_country_by_country_efriction_analysis/, accessed 21.03.2016.

BCG (2014) Greasing the Wheels of the Internet Economy. Available at: https://www.bcgperspectives.com/content/ articles/digital_economy_telecommunications_greasing_wheels_internet_economy/, accessed 21.03.2016. 
Berndt E.R., Hulten C.R. (eds.) (2007) Hard-to-Measure Goods and Services: Essays in Honor of Zvi Griliches, Chicago: The University of Chicago Press.

Bessonov V.A., Brodskii N. IU., Zhuravlev S.V., Stoliarova A.G., Frolov A.S. (2011) O razvitii sektora IKT v rossiiskoi ekonomike [The development of the ICT sector in the Russian economy]. Voprosy Statistiki [Statistics Questions], no 12, pp. 15-30 (in Russian).

Brynjolfsson E., Saunders A. (2010) Wired for innovation: How information technology is reshaping the economy, Cambridge, MA: MIT Press.

Ciocoiu C.N. (2011) Integrating digital economy and green economy: Opportunities for sustainable development. Theoretical and Empirical Researches in Urban Management, vol. 6, no 1, pp. 33-43.

Data Insight (2014) Elektronnaya torgovlya v Rossii [Electronic trade in Russia]. Available at: http://www.datainsight. $\mathrm{ru} /$ ecommerce2014, accessed 27.07.2016 (in Russian).

Deloitte (2011) The Connected Continent. How the Internet Is Transforming The Australian Economy, New York: Deloitte. Available at: http://connected-continent.appspot.com/media/illustrations/download.pdf, accessed 21.03.2016.

EWDN (2013) Internet torgovlya v Rossii [Internet Trade in Russia]. Available at: https://www.rvc.ru/upload/ iblock/0ee/e-commerce_resume_vk_part1_v1.pdf, accessed 27.07.2016.

Greenstein S., McDevitt R.C. (2011) The broadband bonus: Estimating broadband Internet's economic value. Information, vol. 35, no 7, pp. 617-632.

Jorgenson D.W., Stiroh K.J. (2000) Raising the speed limit: U.S. economic growth in the information age. Brookings Papers on Economic Activity, vol. 1, pp. 125-235.

Knight S. (2015) Delivering the digital region: Leveraging digital connectivity to deliver regional digital growth. Australian Planner, vol. 52, no 1, pp. 4-15.

Labaye E., Remes J. (2015) Digital technologies and the global economy's productivity imperative. Digiworld Economic Journal, no 100, pp. 47-64.

McKinsey (2011) Sizing the Internet Economy. Internet Matters: The Net's Sweeping Impact on Growth, Jobs and Prosperity, New York: McKinsey Global Institute.

Morton F.S. (2006) Consumer Benefit from Use of the Internet. Innovation Policy and the Economy, vol. 6 (eds. A.B. Jaffe, J. Lerner, S. Stern), Cambridge: National Bureau of Economic Research.

OECD (2010) OECD Information Technology Outlook 2010, Paris: OECD. Available at: http://www.keepeek.com/ Digital-Asset-Management/oecd/science-and-technology/oecd-information-technology-outlook-2010_it_ outlook-2010-en\#.WK8iWW-LS70, accessed 27.07.2016.

OECD (2011) OECD Guide to Measuring the Information Society, Paris: OECD. Available at: http://www. oecdbookshop.org/browse.asp?pid=title-detail\&lang=en\&ds=\&ISB=9789264113541, accessed 27.07.2016.

OECD (2013) Measuring the Internet Economy, Paris: OECD. Available at: https://www.digital.je/media/SecureStrategic-Documents/OECD\%20-\%20Measuring\%20the\%20Internet\%20Economy\%20-\%202013.pdf, accessed 27.07.2016.

OECD (2014) Measuring the Digital Economy, Paris: OECD. Available at: http://ec.europa.eu/eurostat/ documents/341889/725159/OECD+Manual+Measuring+the+Digital+Economy/6418c566-4074-4461-91869ad509bc4a4d, accessed 27.07.2016.

RAEC (2012) Ekonomika Runeta 2011-2012 [The Economy of Runet 2011-2012], Moscow: The Russian Association of electronic communications Available at: https://www.hse.ru/pubs/share/direct/document/72059988, accessed 27.07.2016 (in Russian).

RAEC (2013) Ekonomika Runeta 2012-2013 [The Economy of Runet 2012-2013], Moscow: The Russian Association of electronic communications. Available at: http://2013.russianinternetweek.ru/upload/files/riw13-researcheconomics-2012-2013.pdf, accessed 27.07.2016 (in Russian).

RAEC (2014) Ekonomika Runeta 2013-2014 [The Economy of Runet 2013-2014], Moscow: The Russian Association of electronic communications. Available at: http://raec.ru/upload/files/er15.pdf, accessed 27.07.2016 (in Russian).

RAEC (2015) Ekonomika Runeta 2014-2015 [The Economy of Runet 2014-2015], Moscow: The Russian Association of electronic communications. Available at: https://www.hse.ru/data/2015/12/16/1134402660/RUNET15_ Booklet_A4_PREVIEW\%20\%25281\%2529.pdf, accessed 27.07.2016 (in Russian).

Rosstat (2015) Natsional'nye scheta Rossii v 2007-2014 [National Accounts of Russia for 2007-2014], Moscow: Federal State Statistics Service (Rosstat) (in Russian).

Shah D.V., Kwak N., Holbert R.L. (2011) 'Connecting' and 'Disconnecting' with Civic Life: Patterns of Internet Use and the Production of Social Capital. Political Communication, vol. 18, no 2, pp. 141-162.

Stiglitz J.E., Sen A., Fitoussi J.-P. (2009) Report by the Commission on the Measurement of Economic Performance and Social Progress, Paris: OFCE - Centre de recherche en économie de Sciences Po.

TCSI Enter (2014) Internet riteilery Rossii po itogam 2013 goda [Internet retailers of Russia in 2013]. Available at: http://www.enter.ru/research, accessed 21.03.2016 (in Russian).

TNS (2014) Auditoriya Internet-proektov [Audience of Internet Projects]. Available at: http://www.tns-global. $\mathrm{ru} /$ services/media/media-audience/internet/information/?arrFilter_pf[YEAR] $=2014 \&$ set_filter=Y, accessed 21.03.2016 (in Russian).

Triplett J. (2006) Handbook on Hedonic Indexes and Quality Adjustments in Price Indexes. Special Application to Information Technology Products, Paris: OECD.

van Welsum D., Overmeer W., van Ark B. (2013) Unlocking the ICT Growth Potential in Europe: Enabling People and Businesses. Using Scenarios to Build a New Narrative for the Role of ICT in Growth in Europe, Brussels: European Commission. Available at: http://bit.ly/2mMCI3L, accessed 27.07.2016. 